\title{
A. M. Giomaro, Sulla presenza delle scuole di diritto e la formazione giuridica nel tardoantico, Rubbettino, Soveria Mannelli 2011,pp. 211.
}

The formation of legal education is always important in the development of societies. Lawyers create statutes, write draft legal acts and are responsible for jurisdiction, and for regulation of governments. Law is present in every walk of our life. Thus, it is necessary to educate properly the people who are important for our growth. The Roman Empire declined between 4 th and 6th centuries. Therefore, it may be helpful now to look at the functioning of law, tribunals and lawyers in the period of collapse of the country. General description of this collapse is a background for description of legal education in Late Antiquity. As a background to the core subject of book, the author also presents the history of sources, that is of Roman legal acts, and provides us with unknown facts about these acts.

The subject and content of the book is "fresh", and it has never been exhaustively described ${ }^{1}$. Until the work of Giomaro there was an observable lack of study that would show us the functioning of legal education in the times when such important acts were written as the Theodosian Code, the Digest, Justinian's Code and the Institutes of Justinian.

Giomaro's book consists of 211 pages in 11 chapters. The author begins it with a very dark and sad description of the Roman Empire in 4th century A.D. as well as of lawyers in this period. Administration of justice was in the hands of praefectus pretorio, as a superior, and in the hands of corrupted judges and advocates who acted together only to gain the highest remuneration, honors and positions.

The author later describes shortly the presence of law schools. The next five chapters talk about the program of studies and attempts at reforming it. This is the longest part of the book, mainly focused on reforms of the program of education and law schools in Justinian's time when, in 533 A.D., in his Constitution Omnem, Justinian substantially modified legal education.

Previously, the program of studies consisted of studying:

- Gai institutiones at the first year of studies,

- Ulpian's Libri ad edictum at the second year of studies,

- Papinian's Responsa at the third year of studies,

1 In the Polish language we may find some articles that touch on the subject of the book, e.g.: K. Kolańczyk, O pochodzeniu prawników rzymskich, „Czasopismo Prawno-Historyczne” 1955, t. 7, z. 1; M. Kuryłowicz, Nauczanie prawa w starożytnym Rzymie, „Filomata” 1975, nr 286; P. Sadowski, Szkoła prawa w Bejrucie w świetle Vita Severi Zachariasza Scholastyka, [w:] Romanitas et christianitas. Stanislao Płodzień (1913-1962) in memoriam, red. A. Dębiński, S. Jóźwiak, Lublin 2008; E. Szabat, Edukacja i kultura $w$ V wieku, [w:] Świat rzymski $w V$ wieku, red. R. Kosiński, K. Twardowska, Kraków 2010. 
- Paulus' works at the fourth year of studies,

- Modestin's works at the fifth year of studies.

The above-mentioned program of studies was modified by introducing legal acts, such as the Theodosian Code and Justinian's Code. From 533 A.D., legal education was focused on the studies of Digest. The Digest was divided into seven parts:

1. books $1-4$ of the Digest, the so called "Prota" (from Greek), part containing fundamental and introductory notions, which also describes legal procedure and law of persons, - studied at the first year of studies, together with the Institutes of Justinian,

2. books 5 - 11 - books about magistrates, judges (de iudiciis), - studied at the second year of studies,

3. books 12 - 19 - books about things (de rebus), - studied at the third year of studies

4. books 20 - 27 - central part of the Digest, describing mortgage and "double" stipulation, redhibitory action (actio redhibitoria), loans, interests, engagement, dowry and tutelage,

5. books 28 - 36 - books about succession, testaments, codicils - private and military ones as well as legates,

- studied jointly at the fourth year of studies,

6. books 37 - 44 - part about bonorum possessio, manumissions, with one book about publicans, repression of frauds and one about obligations and complaints,

7. books 45 - 50 - part about stipulations and verbal obligations, fideiussio, mandates, delicts and crimes, appeals, decurions, public works and services,

- studied together at the fifth year of studies.

In her book Giomaro gives us a clear comparison in tables - a short summary of the programs of education in law schools before and after the reform of education introduced by Justinian. In their study of programs mentioned above students used an important tool - interpretation, which was useful in the study of Responsa, Instutiones, Libri ad Sabinum etc.

Discussion about the reform of studies may be the most important part of this book. Actually, the author starts her book from the sentence "ad illustrare la decadenza della cultura giuridica nel IV - V secolo...", which means "to illustrate the decline of legal culture in the 4th and 5th centuries...". In the first sentence the author expresses her attitude to other facts described in the book, like the reform of legal education and comparison of sources. Thus, legal education must have been in really poor condition if Justinian decided to revolutionize it. Because of that, in the opinion of the author of the reviewed book and, also in the opinion of the author of this review, legal education was modified. Introduction of new sources, like the Theodosian Code or Justinian's legislation "only" provided a base to heal the condition of lawyers and law schools. The educational revolution was absolutely essential.

The author also talks in her book about the "technical" aspects of law: construction of particular acts, division into titles and books in particular legal acts, about the trans- 
formation of acts, previously included in rolls, into codes. According to the author, in Late Antiquity re-structuring ("ri-strutturazione") the works of classical jurisprudence was a common practice. Original works about particular cases and showing a solution of a legal problem in a casuistic way were divided by lawyers in Late Antiquity into titles, books and chapters.

At the time of Justinian it might have been hard to study law in the Greek parts of the Empire, because legal sources, like Justinian's Code, were written in Latin. In the Greek part of the Empire even professors of universities often had a problem with the knowledge of Latin. Thus, a Greek professor had to teach Greek students the law that was written in Latin in the Greek language. The lack of knowledge of the Latin language was a substantial obstacle to learn law well, and this lack of knowledge of the Latin language might also have been a reason for copying legal acts and translating them from Latin into Greek. This practice was banned by Justinian. According to Giomaro, Justinian with his reform of legal education, had the aim to have, in the first place, well-educated "operators" (operatori), to cope with the administration of the large empire, and also to have good lawyers, judges or advocates, who would be responsible for the creation, modification and application of rules of social behavior.

An interesting observation of the author is that we know a lot of names of lawyers and teachers from famous schools of law from the classical times of the Empire. On the contrary, in Late Antiquity lawyers were mostly anonymous.

To sum up this review, the positive sides of the reviewed book are good, exhaustive footnotes and structure with a clear division into coherent chapters. In some of them it may be quite difficult to find valuable information about the core subject of the book, between digressions and citations. Also, too long, in my opinion, descriptions of particular books and titles from the Digest may be questioned. The author probably focused on presenting thoroughly the subject of studies (the Digest) to the readers who currently do not have access to the Digest at all. Moreover, a detailed description of the Digest and quotations from it might seem too long. However, my general impression about the reviewed book is positive. Even the mistakes, like double citations of the same passage from the same book at the same page (for instance, at p. 109), do not change a general, good impression and opinion about the reviewed book. Even though the book contains over 200 pages, the author ends it with a list of problems to solve, connected with the subject of the book. It is clear that there is a role for other researchers of the Roman law and Roman history to solve these problems.

Who is this book for? Generally, for historians, enthusiasts of Roman law and legal history, but also for other people, like students of law, who would like to compare their present style of education with that of students from Late Antiquity, when the most important works of our legal history were written. 